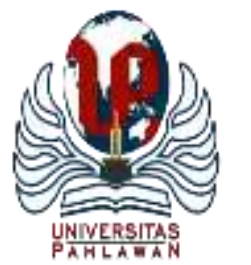

Edukatif : Jurnal Ilmu Pendidikan Volume 3 Nomor 4 Tahun 2021 Halm 2383 - 2390

EDUKATIF: JURNAL ILMU PENDIDIKAN

Research \& Learning in Education

https:/ledukatif.org/index.php/edukatif/index

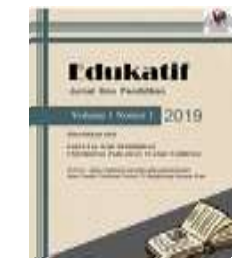

\title{
Penerapan Media Gambar Bertema "Covid-19" dalam Kemampuan Menulis Teks Puisi pada Siswa
}

\author{
Kikih Sumirat $^{1 \bowtie}$, Dewi Herlina Sugiarti², Uah Maspuroh ${ }^{3}$ \\ Universitas Singaperbangsa Karawang, Indonesia ${ }^{1,2,3}$ \\ E-mail : $1710631080087 @$ student.unsika.ac.id ${ }^{1}$, dewi.herlina@fkip.unsika.ac.id ${ }^{2}$, \\ uah.maspuroh@fkip.unsika.ac.id ${ }^{3}$
}

\begin{abstract}
Abstrak
Penelitian ini dilatarbelakangi oleh kurangnya minat siswa dalam menulis teks puisi, terutama di masa pandemi saat ini. Tujuan dalam penelitian ini untuk mengetahui bagaimana nilai pretest kemampuan siswa dalam menulis teks puisi sebelum menggunakan media gambar bertema "Covid-19" pada siswa, dan mengetahui nilai posttest sesudah menggunakan media gambar bertema "Covid-19" dan tanpa diberikan media gambar. Pendekatan penelitian menggunakan kuantitatif dengan desain ekperimen pretest-posttest control group design. Sampel yang digunakan adalah siswa kelas X di SMK Lentera Bangsa sebanyak 2 kelas. Berdasarkan hasil penelitian, diperoleh nilai rata-rata nilai pretest eksperimen lebih tinggi dibandingkan kelas kontrol. Rata-rata nilai pretest kelas kontrol sebesar 67,5, sedangkan rata-rata nilai pretest kelas eksperimen sebesar 73,39. Selanjutnya, rata-rata nilai posttest kelas kontrol sebesar 82,5, rata-rata nilai posttest eksperimen sebesar 87,26. Dapat disimpulkan media gambar bertema "Covid-19" dapat diterapkan dalam kemampuan menulis teks puisi. Hal ini dibuktikan dengan hasil uji perbedaan dua rata-rata pada hasil posttest sebesar 0,004, maka Ho ditolak dan Ha diterima.
\end{abstract}

Kata Kunci: Kemampuan menulis, puisi, media gambar

\begin{abstract}
This research is motivated by the lack of students' interest in writing poetry texts, especially during the current pandemic. The purpose of this study was to find out how the pretest scores of students' abilities in writing poetry texts were before using the "Covid-19"-themed picture media on students, and to find out the post-test scores after using the "Covid-19"-themed picture media and without being given picture media. The research approach uses a quantitative experimental design with pretest-posttest control group design. The sample used is class X students at SMK Lentera Bangsa as many as 2 classes. Based on the results of the study, the average value of the experimental pretest was higher than the control class. The average pretest value for the control class is 67.5, while the average pretest value for the experimental class is 73.39. Furthermore, the average posttest value of the control class was 82.5, the average experimental posttest score was 87.26. It can be concluded that the" Covid-19"-themed image media can be applied in the ability to write poetry texts. This is evidenced by the results of the two average differences in the posttest results of 0.004, then Ho is rejected and Ha is accepted.
\end{abstract}

Keywords: Writing skills, poetry, picture media

Copyright (c) 2021 Kikih Sumirat, Dewi Herlina Sugiarti, Uah Maspuroh

Corresponding author:

Email : 1710631080087@student.unsika.ac.id

DOI : https://doi.org/10.31004/edukatif.v3i4.1237

ISSN 2656-8063 (Media Cetak)

ISSN 2656-8071 (Media Online) 
2384 Penerapan Media Gambar Bertema "Covid-19" dalam Kemampuan Menulis Teks Puisi pada SiswaKikih Sumirat, Dewi Herlina Sugiarti, Uah Maspuroh

DOI: https://doi.org/10.31004/edukatif.v3i4.1237

\section{PENDAHULUAN}

Pada masa pandemi sekarang ini yang sedang marak di berbagai negara terutama di Indonesia, sangat berpengaruh terhadap kegiatan dan pembelajaran belajar mengajar seperti biasanya, sehingga mengakibatkan kegiatan belajar dan mengajar dilakukan di rumah secara daring atau pembelajaran jarak jauh. Pendapat lain mengemukakan "pembelajaran jarak jauh adalah ketika proses pembelajaran tidak terjadinya kontak dalam bentuk tatap muka langsung antara pengajar dan pembelajar (Munir 2012). Menurut Kearsly, Moore (Yerusalem, Rochim, and Martono 2015) mengemukakan pembelajaran jarak jauh adalah belajar yang direncanakan di tempat lain atau di luar tempatnya mengajar. Pembelajaran jarak jauh bisa memanfaatkan jaringan internet pada saat pelaksanaanya. Dalam pembelajaran jarak jauh memerlukan bantuan metode, media, serta strategi pembelajaran yang harus diterapkan oleh pendidik kepada peserta didik agar tidak merasa bosan dalam belajarnya. Adapun salah satu mata pelajaran yang memerlukan strategi pembelajaran yang sesuai dengan pembelajaran jarak jauh yaitu mata pelajaran Bahasa dan Sastra Indonesia.

Pembelajaran Bahasa Indonesia yang meliputi empat keterampilan berbahasa yang harus dikuasai oleh peserta didik, yaitu (1) keterampilan menyimak, (2) berbicara, (3) membaca, dan (4) menulis. Keterampilan ini merupakan satu kesatuan yang tentunya menunjang dalam pembelajaran Bahasa Indonesia. Menulis adalah keterampilan berbahasa yang dimiliki oleh setiap orang. Bahasa yang digunakan dalam puisi berbeda dengan bahasa yang digunakan sehari-hari, puisi menggunakan bahasa yang ringkas, kata-kata yang digunakan konotatif yang mengandung banyak penafsiran dan pengertian (Samosir 2013). Selain itu, menulis merupakan kegiatan berkomunikasi berupa penyampaian informasi secara tertulis dengan media penggunaannya. Dalam kegiatan menulis, harus memperlihatkan struktur kebahasaan bahasa Indonesia yang baik dan benar. Kegiatan menulis adalah sesuatu yang diungkapkan oleh seseorang melalui tulisan-tulisan yang dituangkan atau dipikirkan oleh seorang penulis. Menulis adalah suatu kegiatan yang produktif dan ekspresif (Tarigan 2008). Pada dasarnya, fungsi utama dari tulisan yaitu sebagai alat komunikasi yang dilakukan secara tidak langsung, salah satunya dalam keterampilan menulis teks puisi.

Penelitian ini difokuskan pada kemampuan menulis teks puisi karena, masalah tersebut perlu adanya tindakan yang bertujuan untuk memperbaiki pembelajaran ke depannya, menulis juga suatu hal yang penting pada pembelajaran Bahasa Indonesia. Berdasarkan hasil observasi ketika melaksanakan pembelajaran teks puisi di sekolah, peserta didik masih kesulitan dalam menulis teks puisi. Faktor penyebabnya, yaitu peserta didik merasa kesulitan dalam menuangkan ide atau gagasan ke dalam bentuk tulisan, dan peserta didik merasa kesulitan dalam memilih kata dengan tepat serta kurang memahami bagaimana merangkaikan kata-kata ke dalam sebuah teks puisi. Permasalahan lain yang ditemukan adalah keterbatasan bahan ajar yang menjadi salah satu faktor penyebab rendahnya kemampuan menulis teks puisi yang dimiliki peserta didik. Kurikulum 2013 merupakan kurikulum baru dan sebagian materi yang diajarkan merupakan materi baru sehingga belum banyak referensi serta bahan ajar yang ada untuk menunjang pembelajaran, khususnya dalam pembelajaran menulis teks puisi secara tertulis.

Puisi merupakan karya sastra yang memiliki ciri khas yang tidak dimiliki oeh karya sastra lain. Kekhasan tersebut seperti beberapa pengertian puisi yang diberikan oleh beberapa ahli diantaranya Waluyo (Siswanto 2008) yang mengemukakan bahwa "puisi adalah bentuk karya sastra yang mengungkapkan pikiran dan perasaan penyair secara imajimatif dan disusun dengan mengonsentrasikan struktur fisik dan struktur batinnya". Menurut Huck dalam (Nurgiyantoro 2005), puisi adalah "suatu bentuk pengekspresian kebahasaan yang mengungkapkan sesuatu secara lebih dan mengungkapkannya lewat berbagai bentuk kebahasaan yang lebih intensif daripada ungkapan kebahasaan yang biasanya". Menurut H.B Jasssin (Wahyuni 2014) berpendapat bahwa puisi adalah sebuah karya sastra yang lahir atas dasar perasaan yang di dalamnya terkandung bermacam pikiran dan tanggapan. Sementara Jhon Dreyden (Wahyuni 2014) berpendapat bahwa puisi adalah musik yang tersusun rapi dengan balutan kata- kata menggunakan majas atau perumpamaan. 
2385 Penerapan Media Gambar Bertema "Covid-19" dalam Kemampuan Menulis Teks Puisi pada SiswaKikih Sumirat, Dewi Herlina Sugiarti, Uah Maspuroh

DOI: https://doi.org/10.31004/edukatif.v3i4.1237

Pradopo (Achmad 2016) mengungkapkan bahwa puisi merupakan rekaman dan interpretasi pengalaman manusia yang penting, diubah dalam wujud yang paling berkesan. James Reevas (Achmad 2016) menambahkan bahwa puisi merupakan ekspresi bahasa yang kaya dan penuh daya pikat. Jadi, puisi mampu mengungkapkan secara lebih banyak daripada sekedar apa yang tertulis dan sekaligus ditulis dan diekspresikan lewat bahasa yang khas puisi yang lain daripada bahasa keseharian.

Mengatasi permasalahan-permasalahan di atas, ada enam metode yang bisa digunakan dalam pembelajaran menulis teks puisi, yaitu (a) berdasarkan objek langsung; (b) berdasarkan media gambar; (c) berdasarkan lamunan; (d) berdasarkan cerita; (e) meneruskan puisi; dan (f) mengawali puisi (Suyatno 2004). Teknik pembelajaran menulis dan gambar bertujuan agar siswa dapat menulis dengan cepat berdasarkan gambar yang dilihat (Suyatno 2004). Gambar dan foto adalah media gambar yang sudah lazim dan umum dipakai dalam dunia pendidikan untuk mendukung proses belajar megajar. Gambar atau foto grafi dapat memberikan gambaran tentang segala sesuatu seperti, binatang, orang, tempat, atau peristiwa. Media adalah segala sesuatu yang digunakan untuk menyalurkan pesan dari pengirim ke penerima sehingga dapat merangsang pikiran, perasaan, perhatian dan minat siswa sedemikian rupa sehingga proses belajar terjadi (Sadiman, Arif 2014). Selain itu,gambar merupakan media visual dua dimensi bidang yang tidak transparan (Subana 2011).

Peneliti menggunakan media gambar sebagai salah satu bahan ajar yang dapat meningkatkan pemahaman peserta didik dalam menulis teks puisi, karena pada media gambar ini ada suatu kelebihan yaitu lebih menunjukkan dan lebih terlihat nyata atau realistis. Selain itu, media gambar dapat membatasi keterbatasan pengamatan yang akan dilakukan oleh peneliti pada peserta didik. Pemilihan gambar yang baik untuk kegiatan pengajaran terdapat enam kriteria yang harus diperhatikan yaitu : (a) Keaslian gambar menunjukkan situasi yang sebenarnya, seperti melihat keadaan atau benda yang sesungguhnya (Sadiman 2007). Peneliti menggunakan media gambar berupa gambar virus Covid-19, hal ini bertujuan untuk menarik minat belajar siswa dalam belajar, serta memudahkan siswa dalam mendapatkan gambaran untuk menuangkan ide atau gagasannya dalam menulis teks puisi agar peserta didik dapat mendapatkan hasil karya puisi dengan lebih kreatif.

Dengan media gambar bertema Covid-19 dapat membantu siswa dalam menulis teks puisi dan meningkatkan hasil belajar siswa. Hal ini diperkuat dengan hasil penelitian sebelumnya mengenai media gambar. Pada penelitian (Yuliyanto 2009) yang berjudul "Peningkatan Kemampuan Menulis Puisi Dengan Media Gambar Karikatur Melalui Teknik Pancingan Kata Kunci Siswa Kelas VIII F SMP Negeri 13 Semarang”. Hasil penelitian menunjukkan bahwa media gambar karikatur dengan teknik pancingan kata kunci dapat membantu dan memudahkan siswa dalam menulis puisi. Hal ini dibuktikan dengan hasil penelitian yang menunjukkan adanya peningkatan keterampilan menulis puisi dengan media gambar karikatur melalui teknik pancingan kata kunci yang dapat dilihat berdasarkan hasil tes siswa kelas VIII F SMP Negeri 13 Semarang, yang meliputi hasil tes siklus I dan siklus II. Koefisien peningkatan tersebut sebesar 11,57\% dari siklus I ke siklus II. Hasil tes siklus I mencapai skor 71 dan pada siklus II meningkat sebanyak 9,29 menjadi 80,29 . Hasil yang dicapai tersebut sudah memenuhi target yang telah ditetapkan. Peningkatan nilai rata-rata ini membuktikan keberhasilan pembelajaran menulis puisi dengan media gambar karikatur.

Selanjutnya penelitian yang dilakukan oleh Hasnah dengan judul "Kemampuan Menulis Puisi Berbantuan Media Gambar Siswa Kelas VIII SMP Negeri 27 Padang”, media gambar dalam penelitian ini menunjukkan hasil yang dapat meningkatkan kemampuan siswa dalam menulis puisi. Hal ini dapat dibuktikan dengan: (1) kemampuan menulis puisi berbantuan media gambar siswa kelas VIII SMP Negeri 27 Padang untuk indikator diksi tergolong baik sekali (BS) dengan rata-rata 88,17 berada pada rentangan $86-95 \%$ pada skala 10, (2) kemampuan menulis puisi berbantuan media gambar siswa kelas VIII SMP Negeri 27 Padang untuk indikator citraan tergolong baik sekali (BS) dengan rata-rata 91,31 berada pada rentangan 86-95\%, (3) kemampuan menulis puisi berbantuan media gambar siswa kelas VIII SMP Negeri 27 Padang untuk indikator 
2386 Penerapan Media Gambar Bertema "Covid-19" dalam Kemampuan Menulis Teks Puisi pada SiswaKikih Sumirat, Dewi Herlina Sugiarti, Uah Maspuroh

DOI: https://doi.org/10.31004/edukatif.v3i4.1237

majas tergolong cukup (C) dengan rata-rata 59,14 berada pada rentangan 56-65\% pada skala 10, dan (4) kemampuan menulis puisi berbantuan media gambar siswa kela VIII SMP Negeri 27 Padang untuk gabungan ketiga indikator tergolong baik (B) dengan rata-rata 79,93 berada pada rentangan $76-85 \%$ pada skala 10 , dan media gambar dianggap berhasil dalam meningkatkan kemapuan menulis puisi siswa (Sharp et al. 2016).

Pada penelitian sebelumnya, media gambar bertema "Covid-19" belum pernah digunakan dalam pembelajaran terutama pada masa pandemi saat ini. Oleh karena itu, peneliti akan melakukan penelitian dengan judul "Penerapan Media Gambar Bertema "Covid-19" Dalam Kemampuan Menulis Teks Puisi Pada Siswa SMK". Penelitian ini dilakukan untuk mengetahui adakah peningkatan pada penerapan media gambar bertema "Covid-19" dalam kemampuan menulis teks puisi siswa.

\section{METODE PENELITIAN}

Berdasarkan tujuan penelitian, metode yang digunakan dalam penelitian ini adalah metode kuantitatif. Penelitian kuantitatif adalah penelitian yang digunakan untuk meneliti pada populasi atau sampel tertentu, pengumpulan data menggunakan instrumen penelitian, analisis data bersifat kuantitatif atau statistik, dengan tujuan untuk menguji hipotesis yang telah ditetapkan (Sugiyono 2015).

Desain yang digunakan dalam mengumpulkan data penelitian ini yaitu desain eksperimen Pretest Posttest Control Group Design. Metode eksperimen adalah metode yang digunakan untuk mencari pengaruh perlakuan tertentu terhadap yang lain dalam kondisi yang terkendali, kondisi yang terkendali dimaksud adalah adanya hasil dari penelitian dikonversikan ke dalam angka-angka untuk analisis yang digunakan dengan menggunakan analisis statistik (Sugiyono 2010). Populasi adalah keseluruhan objek atau subjek dalam penelitian. Adapun pendapat lain mengemukakan populasi adalah wilayah generalisasi yang terdiri atas objek atau subjek yang mempunyai kualitas dan karakteristik tertentu yang ditetapkan peneliti, kemudian ditarik kesimpulan (Sugiyono 2015). Populasi dalam penelitian ini adalah seluruh siswa di SMK Lentera Bangsa, Kabupaten Karawang, Provinsi Jawa Barat tahun ajaran 2020/2021.

Sampel adalah bagian dari jumlah dan karakteristik yang dimiliki oleh populasi tersebut (Sugiyono 2015). Sampel yang dipilih dalam penelitian ini sebanyak dua kelas yaitu pada kelas $X$ yaitu kelas $X$ TKJ 1 dan X RPL 1. X TKJ 1 dengan jumlah 31 siswa sebagai kelas eksperimen dan X RPL 1 dengan jumlah 24 siswa sebagai kelas kontrol.

Teknik pengumpulan data merupakan suatu yang berkenaan dengan langkah-langkah yang harus dilakukan dalam memperoleh data. Teknik pengumpulan data dalam penelitian ini adalah pemberian tes, dan dokumentasi. Pretest diberikan kepada dua kelas yang menjadi sampel penelitian dengan tujuan untuk mengetahui sejauh mana siswa mengenal dan memahami materi pelajaran yang akan diajarkan. Kemudian posttest pun diberikan kepada dua kelas tersebut untuk mengetahui apakah materi yang diberikan, telah dikuasai atau dimengerti dengan baik oleh siswa. Terdapat perbedaan dalam pembelajaran dan pemberian posttest, yaitu kelas kontrol tidak mendapatkan perlakuan dengan media gambar, sedangkan kelas eksperimen mendapatkan perlakuan dengan media gambar bertema"Covid-19". Teknik pengolahan data dan analisis data dihitung dengan menggunakan program SPSS 20.

Adapun instrumen penelitian menggunakan tes yaitu pretest dan posttest. Pretest diberikan kepada dua kelas sebelum diberikan materi pelajaran, dan posttest diberikan kepada dua kelas juga tetapi dalam posttest adanya pemberian materi yang bertujuan untuk mengetahui apakah materi yang diberikan sudah dikuasai oleh siswa atau belum. Lalu terdapat perbedaan dalam proses pembelajaran dan posttest. Posttest pada kelas Kontrol tidak diberikan perlakuan media gambar, sedangkan pada posttest kelas eksperimen diberikan perlakuan media gambar.

\section{HASIL DAN PEMBAHASAN PENELITIAN}

Edukatif : Jurnal Ilmu Pendidikan Vol 3 No 4 Tahun 2021 p-ISSN 2656-8063 e-ISSN 2656-8071 
2387 Penerapan Media Gambar Bertema "Covid-19" dalam Kemampuan Menulis Teks Puisi pada SiswaKikih Sumirat, Dewi Herlina Sugiarti, Uah Maspuroh

DOI: https://doi.org/10.31004/edukatif.v3i4.1237

Tahapan ini bertujuan untuk mengetahui hasil pretest kelas eksperimen dan kelas kontrol sebelum diberikan perlakuan, dan untuk mengetahui hasil posttest kelas eksperimen yang diberikan perlakuan dengan menggunakan media gambar dan kelas kontrol yang tidak diberikan perlakuan. Sampel dalam penelitian adalah kelas X, yang akan dijadikan sampel terdiri dari dua kelas, yaitu kelas eksperimen dan kelas kontrol. Adapun sampel penelitian ini menggunakan kelas X Teknik Komputer dan Jaringan (TKJ) 1 sebagai kelas eksperimen yang menggunakan media gambar, dengan jumlah 31 siswa, dan kelas X Rekayasa Perangkat Lunak (RPL) 1 sebagai kelas kontrol yang tidak menggunakan media gambar dengan jumlah 24 siswa.

Sebelum diberikan media gambar, terlebih dahulu kelas tersebut diberikan tes awal (pretest) untuk mengetahui kemampuan awal dan kemampuan menulis puisi yang dimiliki siswa, kemudian setelah semua materi selesai, kelas tersebut diberi tes akhir (posttest) untuk melihat kemampuan siswa setelah diterapkannya media gambar bertema "Covid-19". Materi yang diberikan adalah menulis teks puisi.

Penelitian ini merupakan penelitian kuantitatif. Data kuantitatif diperoleh dari pretest, posttest baik kelas eksperimen maupun kelas kontrol. Kelas eksperimen dilakukan pembelajaran dengan menggunakan media gambar bertema "Covid-19", sedangkan kelas kontrol dengan menggunakan pembelajaran biasa tanpa diberikan media pembelajaran. Analisis dilakukan dengan bantuan software SPSS versi 20. untuk pengolahan data. Berikut ini merupakan deskripsi pretest dan posttest pada kelas eksperimen dan kelas kontrol.

Tabel 1

Statistik Deskriptif Kemampuan Menulis Teks Puisi Siswa

\begin{tabular}{llll}
\hline Kelas & $\begin{array}{l}\text { Nilai } \\
\text { Terendah }\end{array}$ & $\begin{array}{l}\text { Nilai } \\
\text { Tertinggi }\end{array}$ & Rata-rata \\
\hline Pretest Eksperimen & 65 & 90 & 73,39 \\
\hline Posttest Eksperimen & 70 & 95 & 87,26 \\
\hline Pretest Kontrol & 60 & 80 & 67,50 \\
\hline Posttest Kontrol & 70 & 90 & 82,50 \\
\hline
\end{tabular}

Berdasarkan tabel 1 di atas, diperoleh nilai rata-rata pretest eksperimen lebih tinggi dibandingkan kelas kontrol. Rata-rata nilai pretest eksperimen sebesar 73,39, sedangkan rata-rata nilai pretest kelas kontrol sebesar 67,50. Selanjutnya, rata-rata nilai posttest kelas eksperimen sebesar 87,26 . Sedangkan rata-rata nilai posttest kontrol sebesar 82,5. Dapat disimpulkan bahwa terdapat peningkatan pada nilai posttest karena sudah diberikan materi pembelajaran.

Kelas eksperimen diperoleh data sebanyak 31 siswa. Pada kelas eksperimen terdapat mean nilai pretest 73,39 dan nilai posttest 87,26. Selanjutnya nilai pretest sebelum diberikan materi, diketahui nilai minimum 65 dan meningkat pada nilai posttest menjadi 90. Begitupun nilai maksimum mengalami peningkatan yaitu dari 90 menjadi 95 pada nilai posttest. Dapat disimpulkan bahwa nilai posttest meningkat karena saat diberikan materi pembelajaran dan posttest, kelas eksperimen diberikan perlakuan dengan media gambar bertema"Covid-19". Jika membandingkan hasil nilai pretest kelas kontrol dengan nilai pretest kelas eksperimen, dapat dilihat pada tabel 1 yaitu mengalami peningkatan yang signifikan. Selanjutnya perbandingan nilai posttest kelas kontrol dengan nilai posttest kelas eksperimen, juga mengalami peningkatan. Hal ini karena kelas kontrol tidak mendapat perlakuan dengan media gambar bertema"Covid-19". Kemudian data diuji normalitas dan homogenitasnya, sebelum melakukan uji hipotesis. Berikut ini adalah hasil uji normalitas dan homogenitas yang diuji dengan program SPSS 20.

Tabel 2

Edukatif : Jurnal Ilmu Pendidikan Vol 3 No 4 Tahun 2021 p-ISSN 2656-8063 e-ISSN 2656-8071 
2388 Penerapan Media Gambar Bertema "Covid-19" dalam Kemampuan Menulis Teks Puisi pada SiswaKikih Sumirat, Dewi Herlina Sugiarti, Uah Maspuroh

DOI: https://doi.org/10.31004/edukatif.v3i4.1237

\begin{tabular}{|c|c|c|}
\hline Uji & est $\mathrm{Ke}$ & Foks F \\
\hline Kelas & Signifikan & Keterangan \\
\hline Pretest Eksperimen & 0,101 & $\mathrm{H}_{\mathrm{a}}$ diterima \\
\hline Pretest Kontrol & 0,056 & $\mathrm{H}_{\mathrm{a}}$ diterima \\
\hline
\end{tabular}

Berdasarkan tabel 2 di atas nilai signifikan skor pretest pada kelas eksperimen adalah 0,101 sehingga berdasarkan kriteria pengujian hipotesis untuk kelas eksperimen lebih dari $\alpha=0,05^{\alpha=0,05}$ maka $\mathrm{H}_{\mathrm{a}}$ diterima yaitu artinya data pretest pada kelas eksperimen berdistribusi normal. Sedangkan untuk kelas kontrol nilai signifikannya adalah 0,056 , karena nilai signifikan kelas kontrol lebih dari $\alpha=0,05^{\alpha=0,05}$ maka $\mathrm{H}_{\mathrm{a}}$ diterima, dengan demikian untuk data pretest pada kelas kontrol berdistribusi normal. Karena data berdistribusi normal, maka dilanjutkan dengan uji normalitas posttest kemampuan menulis teks puisi.

Tabel 3

\begin{tabular}{|c|c|c|}
\hline il Uji Nor & test Keman & Is Teks Puis \\
\hline Kelas & Signifikan & Keterangan \\
\hline Posttest Eksperimen & 0,052 & $\mathrm{H}_{\mathrm{a}}$ diterima \\
\hline Posttest Kontrol & 0,056 & $\mathrm{H}_{\mathrm{a}}$ diterima \\
\hline
\end{tabular}

Berdasarkan tabel 3 di atas, diperoleh nilai signifikansi berdasarkan uji Kolmogorov-Smirnov ${ }^{a}$ untuk kemampuan menulis teks puisi pada kelas yang diberikan media gambar bertema "Covid-19" Sig =0, $52>\alpha$ $=0,05$, Sig $=0,52>\alpha=0,05$, maka $\mathrm{H}_{\mathrm{a}}$ diterima artinya data posttest berasal dari populasi data berdistribusi normal. Pada kelas yang diberikan pembelajaran biasa Sig $=0,056>\alpha=0,05$ Sig $=0,056>\alpha=0,05$, maka $\mathrm{H}_{\mathrm{a}}$ diterima artinya data posttest berasal dari populasi berdistribusi normal.

Karena data berdistribusi normal, maka dilanjutkan dengan uji homogenitas untuk data pretest dan posttest kemampuan menulis teks puisi pada kelas yang diberikan media gambar bertema covid-19 dan kelas yag tidak diberikan media.

Tabel 4

Hasil Uji Homogenitas Skor Pretest Kemampuan Menulis Teks Puisi Siswa

\begin{tabular}{ll}
\hline Sig & Keterangan \\
\hline 0,245 & $\mathrm{H}_{\mathrm{a}}$ diterima
\end{tabular}

Berdasarkan tabel 4 di atas diperoleh besar signifikansi adalah 0,245. Nilai signifikansi tersebut lebih dari 0,05 (sig. $>0,05$ ) berarti $\mathrm{H}_{\mathrm{a}}$ diterima. Jadi secara signifikansi data pretest kelas eksperimen dan kelas kontrol mempunyai varians yang homogen. Adapun hasil uji homogenitas nilai posttest kemampuan menulis teks puisi sebagai berikut.

Tabel 5

Hasil Uji Homogenitas Skor Posttest Kemampuan Menulis Teks Puisi Siswa

\begin{tabular}{ll}
\hline Sig & Keterangan \\
\hline 0,707 & $\mathrm{H}_{\mathrm{a}}$ diterima \\
\hline
\end{tabular}

Berdasarkan tabel di atas diperoleh besar signifikansi adalah 0,707. Nilai signifikansi tersebut lebih dari 0,05 (sig. > 0,05) berarti $\mathrm{H}_{\mathrm{a}}$ diterima. Jadi secara signifikansi data posttest kelas eksperimen dan kelas kontrol mempunyai varian yang homogen. Maka, dapat dilanjutkan dengan uji perbedaan dua rata-rata dari data yang diperoleh.

Tabel 6

Uji Perbedaan Dua Rata-Rata Skor Pretest Kemampuan Menulis Teks Puisi Siswa Sig. (2-tailed) Keterangan 
2389 Penerapan Media Gambar Bertema "Covid-19" dalam Kemampuan Menulis Teks Puisi pada SiswaKikih Sumirat, Dewi Herlina Sugiarti, Uah Maspuroh

DOI: https://doi.org/10.31004/edukatif.v3i4.1237

$0,001 \quad \mathrm{H}_{\mathrm{o}}$ ditolak dan Ha diterima

Pada tabel 5 di atas diperoleh nilai Sig. (2-tailed) adalah 0,001. Jika dilihat pada dasar pengambilan keputusan, hasil uji hipotesis menghasilkan nilai signifikansi $<0,05$. Maka, dapat disimpulkan Ho ditolak dan Ha diterima yaitu terdapat peningkatan dalam penerapan media gambar bertema covid-19 dalam kemampuan menulis teks puisi pada siswa kelas X di SMK Lentera Bangsa. Adapun hasil uji perbedaan dua rata-rata nilai posttest kemampuan menulis teks puisi sebagai berikut.

Tabel 7

Uji Perbedaan Dua Rata-Rata Skor Posttest Kemampuan Menulis Teks Puisi Siswa

\begin{tabular}{ll}
\hline Sig. (2-tailed) & Keterangan \\
\hline 0,004 & $\mathrm{H}_{\mathrm{o}}$ ditolak dan Ha diterima
\end{tabular}

Pada tabel 6 di atas diperoleh nilai Sig. (2-tailed) adalah 0,004. Jika dilihat pada dasar pengambilan keputusan, hasil uji hipotesis menghasilkan nilai signifikansi $<0,05$. Maka, dapat disimpulkan Ho ditolak dan Ha diterima yaitu terdapat peningkatan dalam penerapan media gambar bertema covid-19 dalam kemampuan menulis teks puisi pada siswa kelas X di SMK Lentera Bangsa.

Kemampuan menulis teks puisi yang sudah dilakukan dengan penerapan media gambar bertema "Covid19" menunjukkan hasil yang meningkat, yaitu adanya peningkatan pada hasil posttest setelah diberikan materi pembelajaran dan perlakuan dengan media gambar bertema "Covid-19". Adapun perbedaan hasil posttest pada kelas eksperimen dan kelas kontrol yang menunjukkan hasil menulis teks puisi pada kelas eksperimen lebih tinggi jika dibandingkan dengan kelas kontrol. Dapat disimpulkan bahwa adanya peningkatan hasil menulis teks puisi dengan penerapan media gambar bertema"Covid-19" dalam kemampuan menulis teks puisi siswa.

Hasil penelitian ini sejalan dengan beberapa penelitian yang telah dilakukan. Hasil penelitian (Yuliasari 2015) menunjukkan bahwa media gambar dapat dinilai efektif untuk menyampaikan materi pembelajaran, terutama pembelajaran menulis puisi dibandingkan dengan pembelajaran biasa. Selain itu penelitian yang dilakukan oleh Ayunina yang mengemukakan bahwa penerapan media gambar dapat meningkatkan kreatifitas dan imajinasi peserta didik, serta ide-ide tersebut muncul ketika peserta didik sudah diberikan media gambar. Proses pembelajaran dengan media gambar menuntut seorang pendidik untuk bisa kreatif dalam menyajikan (Multikasus et al. 2016). Dengan diterapkannya media gambar bertema "Covid-19" dapat memudahkan siswa dalam menuangkan ide atau gagasannya dalam menulis teks puisi, karena siswa dapat melihat gambar yang telah diberikan sehingga siswa dengan mudah dalam menuangkannya ke dalam bentuk tulisan.

\section{KESIMPULAN}

Berdasarkan penelitian yang dilakukan pada kelas X TKJ 1 dan X RPL 1 di SMK Lentera Bangsa Karawang, kemampuan menulis teks puisi dengan media gambar menunjukkan hasil yang meningkat. Hal ini dibuktikan pada hasil posttest siswa kelas eksperimen lebih tinggi jika dibandingkan dengan kelas kontrol. Dapat disumpulkan bahwa media gambar bertema "Covid-19" berhasil diterapkan dalam kemampuan menulis teks puisi siswa, karena hasil menulis puisi siswa meningkat. Sehingga dapat disarankan dalam pembelajaran, dan hendaknya pendidik berinovasi terhadap media pembelajaran yang lebih menarik. Maka dari itu, dapat menerapkan media gambar bertema "Covid-19" pada pembelajaran mata pelajaran lainnya, khususnya dalam pembelajaran Bahasa Indonesia yaitu menulis teks puisi.

\section{UCAPAN TERIMA KASIH}

Puji syukur atas rahmat Allah SWT, atas karunia serta rahmatnya yang telah memberikan kelancaran dan kemudahan dalam menyelesaikan penelitian hingga membuat artikel ini. Terima kasih peneliti ucapkan 
2390 Penerapan Media Gambar Bertema "Covid-19" dalam Kemampuan Menulis Teks Puisi pada SiswaKikih Sumirat, Dewi Herlina Sugiarti, Uah Maspuroh

DOI: https://doi.org/10.31004/edukatif.v3i4.1237

untuk kedua orang tua atas dukungan dan doa yang tiada hentinya. Terima kasih kepada dosen pembimbing Universitas Singaperbangsa Karawang, kepala sekolah SMK Lentera Bangsa, serta guru bahasa Indonesia dan staff, dan untuk teman-teman seperjuangan atas segala bantuan dan bimbingannya sehingga peneliti dapat menyelesaikan penelitian ini.

\section{DAFTAR PUSTAKA}

Achmad, Sri Wintala. 2016. Menulis Kreatif Itu Gampang. Yogyakarta.

Hasnah, N. 2016. "Kemampuan Menulis Puisi Berbantuan Media Gambar Siswa Kelas VIII SMP Negeri 27 Padang"

Multikasus, Studi et al. 2016. "Penggunaan Media Gambar Dalam Keterampilan Pascasarjana Iain Tulungagung Juni 2016."

Munir. 2012. Pembelajran Jarak Jauh Berbasis Teknologi Informasi Dan Komunikasi. Bandung.

Nurgiyantoro, Burhan. 2005. Sastra Anak. Yogyakarta.

Sadiman, Arif, Dkk. 2014. Media Pendidikan. Depok.

Sadiman, Arief. S. 2007. Media Pendidikan. Jakarta.

Samosir, Trioda. 2013. Apresiasi Puisi. Bandung.

Siswanto, Wahyudi. 2008. Pengantar Teori Sastra. Jakarta.

Subana, Dkk. 2011. Strategi Belajar Mengajar Bahasa Indonesia Berbagai Pendidikan Metode, Teknik, Dan Media Pembelajaran. Jakarta.

Sugiyono. 2010. Statistik Untuk Penelitian. Bandung.

Sugiyono. 2015. Metodologi Penelitian. Bandung.

Suyatno. 2004. Teknik Pembelajaran Bahasa Dan Sastra. Surabaya.

Tarigan, Henry Guntur. 2008. Menyimak. Bandung.

Wahyuni, Ristri. 2014. Kitab Lengkap Puisi, Prosa, Dan Pantun Lama. Yogyakarta.

Yerusalem, Muhammad Rozi, Adian Fatchur Rochim, and Kurniawan Teguh Martono. 2015. "Desain Dan Implementasi Sistem Pembelajaran Jarak Jauh Di Program Studi Sistem Komputer.” Jurnal Teknologi dan Sistem Komputer 3(4): 481.

Yuliasari, Lia. 2015. "Peningkatan Keterampilan Menulis Puisi Dengan Media Gambar Pada Siswa Kelas Iii Mi MathlaUl Anwar Pamungguan Bogor."

Yuliyanto. 2009. "Peningkatan Kemampuan Menulis Puisi Dengan Media Gambar Karikatur Melalui Teknik Pancingan Kata Kunci Siswa Kelas VIII F SMP Negeri 13 Semarang Tahun Pelajaran 2008/2009.” 